\title{
Platelet-Activating Factor Acetylhydrolase IB Subunit Alpha
}

National Cancer Institute

\section{Source}

National Cancer Institute. Platelet-Activating Factor Acetylhydrolase IB Subunit Alpha. NCI Thesaurus. Code C75887.

Platelet-activating factor acetylhydrolase IB subunit alpha (410 aa, $\sim 47 \mathrm{kDa}$ ) is encoded by the human PAFAH1B1 gene. This protein is involved in neuronal migration. 